\title{
Entre a poeira e o silêncio Sobre exposições e construções da memória no Museu do Ceará (1932-1997)
}

\author{
Francisco Régis Lopes Ramos ${ }^{1}$
}

RESUMO $\bigcirc$ artigo aborda algumas maneiras de construir os sentidos do passado nas exposições do Museu do Ceará entre os anos 1932 e 1997. Com base em problemáticas da história social da memória, são destacados os sentidos da poeira e do silêncio no modo pelo qual o pretérito é configurado no espaço das exposições. Desse modo, os artefatos são tratados a partir de valores e expectativas que orientam, em determinada circunstância, as conexões e as separações entre passado e presente.

PALAVRAS-CHAVE: Museu. Memória. Objeto. Percepção. Escrita da História. Exposição.

ABSTRACT This article discusses some manners to construct the meanings of the past into Museu do Ceará's exhibitions between 1932 and 1997. Based on issues of Social History of Memory, the meanings of dust and silence are highlighted in a way that the past is configured in the space of the exhibitions. The artifacts are treated taking into account underlying values and expectations that guide, in certain circumstances, connections and separations between past and present.

KEYWORDS: Museum. Memory. Object. Perception. History Writing. Exhibition.

A poeira do passado e o perigo do presente

Depois de criado, em 1932, o Museu Histórico do Ceará passou a receber significativa variedade de doações, motivada pela política oficial do estado cearense e pelo empenho de seu primeiro diretor, o juiz Eusébio de Sousa. Como era de se esperar, moedas e medalhas - ao lado de coisas que lembravam heróis e fatos patrióticos.
1. Professor do Departamento do História da Universidade Federal do Ceará (UFC). Doutor em História Social pela Pontifícia Universidade Católica de São Paulo (PUC-SP). O autor agradece ao historiador José Neves Bittencourt o incentivo e o desafio para escrever o presente texto. 
2. Cf. Asmuce (2007, p. 6468).

3. Cf. Ulpiano B. de Meneses (2007, p. 122).

4. Ibidem.
As doações mais valorizadas eram as vinculadas aos chamados "objetos biográficos", ou seja, marcados pelo nome de quem os possuía. Mas muitos outros artefatos apareceram. Eusébio aceitava praticamente tudo que pudesse chamar atenção. Ao contrário do que se costuma pensar a respeito dos chamados "museus históricos", houve um acúmulo de coisas não necessariamente vinculadas a datas, eventos ou personalidades destacadas. Cito, nesse sentido, algumas doações registradas entre julho e setembro de 1933, tal como foram publicadas em jornal, com a identificação do doador e de sua cidade:

Pelo sr. Antônio Franklin do Nascimento, Fortaleza: antigo Dicionário da língua portuguesa, de Morais, dois volumes. Pelo sr. Ataualpa de Alencar, Fortaleza: um machado de pedra, indígena. Pelo sr. Aristides Chagas Moreno, Quixadá: um bloco de calcário sacaróide (mármore), tirado de uma pedreira existente na fazenda Vidéo, de sua propriedade. Pelo sr. Manfredo de Oliveira Lima, Limoeiro: um par de estribos de ferro. Pelo sr. José Abreu do Nascimento, Fortaleza: um fóssil-peixe, original da cidade do Crato; curativo de emergência, acondicionado em caixa de metal, usado pelos revoltosos paulistas de 1932; carteira de cigarros 9 de Julho, usada pelos mesmos revolucionários, em 1932. Pelo colegial Eliomar Saraiva, aluno do Instituto S. Luís, Fortaleza: um espelho antigo².

Para qualificar o acervo acumulado, jornais da época usavam termos como "relíquia", "curiosidade" ou "raridade". Por um lado, poder-se-ia imaginar que tudo isso teria conexões com a sensibilidade antiquária - que resistia diante das novas configurações da escrita da história, calcadas no cientificismo e nos métodos de investigação que ganharam corpo no decorrer do século XIX. Por outro lado, a questão não deve ser assim reduzida.

Ulpiano Bezerra de Meneses adverte que não se deve tratar os "Museus Brasileiros" como cópias de modelos europeus. Se, por um lado, o saber do antiquário não tornará "o passado em presença materializada nos objetos que o circundam", por outro, o historiador não terá êxito em transformar "o passado distante em objeto de reflexão científica, intelectual" 3 . O autor cita, de modo rápido e certeiro, uma comparação entre procedimentos do Museu Histórico Nacional e do Museu Paulista, para evidenciar as nossas particularidades contraditórias, que estão a carecer de um enfrentamento interpretativo. Gustavo Barroso (no Museu Histórico Nacional) e Affonso Taunay (no Museu Paulista) seguiram motivações e caminhos que impedem qualquer tipo de unidade. "Basta dizer que, enquanto Barroso parte de uma ampla e sistemática coleção de armaria, Taunay chega a desenvolver um programa de encomenda de imagens a artistas de sua confiança, para adaptar e ressignificar fotografias metamorfoseadas em telas a óleo." 4

No Museu Histórico do Ceará, também Eusébio de Sousa acabou fazendo sua mistura, longe de qualquer tentativa de padronização. Assim como Gustavo Barroso, ele cultuava armarias. E, ainda, seguiu o exemplo de Taunay, encomendando o serviço de pintores, como é o caso de J. Carvalho, que fez em óleo sobre tela imagens fotográficas ou, até, habitantes da imaginação. Cito, para não me alongar, apenas duas encomendas: $\bigcirc$ Sobrado onde foi preso o 
Pe. Mororó (herói da Confederação do Equador), e a imagem do General Tibúrcio (herói da Guerra do Paraguai).

A especificidade do espaço museológico constituía-se via tradições, que podem estar tanto em confronto como em colaborações, seja com nacionalismo, regionalismo, romantismo, iluminismo ou sensibilidade antiquária. Seria temerário escolher apenas um termo para caracterizar o direcionamento promovido por Eusébio de Sousa. Mas, de qualquer modo, vale sublinhar que nada disso estava "solto no ar". Não se pode, afinal, tratar esse imbróglio de (con)tradições sem referenciar as íntimas relações entre a instituição do poder da memória e a memória do poder instituído.

Ao contrário das conclusões generalizantes sobre a existência de museus ditos "tradicionais", aquilo que hoje genericamente pode ser chamado de "cultura popular" não estava ausente do acervo reunido por Eusébio de Sousa. Os "objetos do povo" não eram exemplos mas sim exemplares da "ingenuidade popular". Note-se o tom dessa matéria de 1933:

TIBÚRCIO CAÍDO, DE PÉ UMA LEMBRANÇA DA TRAGÉDIA DE 1914. OUTRAS CURIOSIDADES - Suspenso à parede, entre vários quadros curiosos, um flagrante fotográfico precioso. A praça General Tibúrcio. Vendo-se o velho Palácio da Luz, na sua feição antiga, de biqueiras descobertas, com as paredes cheias de buracos produzidos por bala, quando da deposição do general José Clarindo.

Ao centro da praça o monumento ao "Caboclo de Viçosa". O vulto do general, talhado no bronze, fora atingido por um balaço e caiu. Mas caiu de pé... Noutro quadro, uma figura extravagante. $O$ dr. Eusébio nos esclarece:

- É a beata Maria de Araújo...

Vendo aquele vulto singular da vida cearense passar assim à historia, não se contém uma exclamação:

- Ah! É esta senhora? Muito prazer em conhecê-la, "santinha"5.

Para os jornais que, nos anos de 1930, vislumbravam o museu, o movimento religioso de Juazeiro estava no plano do monstruoso, do feio, da degenerescência. Não era normal o corpo que se entregava aos ritos da autoflagelação, assim como não era católico quem acreditava nos milagres da beata Maria de Araújo, ocorridos no final do século XIX. Talhado em bronze, o general Tibúrcio, herói cearense na Guerra do Paraguai, contrastava com a beata, mas ambos estavam lá, no mesmo espaço de memória. Mas em que medida percebia-se essa mistura? É plausível imaginar o objeto vertical em si mesmo, objetivo em sua própria materialidade, e capaz de trazer o passado em sua própria existência. Os contrastes, nesse sentido, podem ser aparentes, como explica um visitante que centrou foco em uma vitrine:

Ao lado de um formoso Nevers dos famosos jarrões de decorações orientais, que jaziam esquecidos na fonte do Passeio Público, dos pratos pseudo-Sèvres do 2. Império, trazendo, em dourado, as iniciais de Pedro II e monograma hialino de Caxias, depara-se-nos pequena malga indígena, encontrada na região do baixo Jaguaribe [...]. Trabalho em pedra, mas de 
6. Idem, p. 78.

7. Idem, p. 121.

8.Abdias Lima (1946, p. 137).

9. Eusébio de Sousa (1938).

10. Idem, p. III.

11. Ibidem. admirável perfeição, denotando já o apuro dos nossos silvícolas na indústria cerâmica da pedra polida. [...] Contraste, pois, só apenas aparentemente chocante ${ }^{6}$.

Apesar das conexões possíveis, cada objeto tinha sua importância. Essa parece ser a regra. Se era assim, não haveria propriamente um contraste inconciliável entre Tibúrcio e Maria de Araújo, entre cerâmica indígena e cerâmica civilizada. Essas coisas eram tão diferentes, tão singulares, que não se chocavam. Mas as reclamações em torno desse jeito de expor seriam recorrentes nas décadas seguintes.

Em uma reportagem, publicada em julho de 1945, o jornalista avisa ao leitor que a recordação acionada pelas peças expostas seria não somente um exercício do raciocínio, na medida em que havia ali o aroma do passado: "até o ar que se respira tem o cheirinho bom das 'coisas que o tempo levou'"7.

É claro que, nesse fluxo discursivo, não se tem o exemplo do espírito de uma época ou a visão geral sobre o museu na década de 1940. Trata-se de uma percepção mais ou menos particular. Mas, na particularidade, há indícios da valorização que se dava às visitas ao museu. Nesse sentido, a vontade que localizava as "curiosidades do passado" convocava, junto com a visão, os outros sentidos, especialmente o olfato. Não é à toa que, ao dar uma entrevista para o livro Falam os intelectuais do Ceará, Eusébio de Sousa dá destaque ao seu próprio nariz:

Somente anos depois, "bacharel formado" [...], é que manifestei o gosto pelo estudo da história tornando-me então inveterado rebuscador de velharias, remexendo papéis antigos, carcomidos pela traça, o que para mim constitui grande prazer, pois, como disse alguém, há em todos os segredos dos arquivos públicos uma recordação, e um pouco de saudade nos invade a alma quando revemos coisas antiquadas. A poeira que elas envolvem é mais suave, é mais macia que a poeira de todos os dias, tem algo de grave, de solene, de recordativo ${ }^{8}$.

A contraposição entre a poeira do passado e a poeira do progresso é tão cara a Eusébio de Sousa que ele repete a mesma estratégia discursiva na apresentação do livro Coisas que o tempo levou', uma coletânea de crônicas, inicialmente para leitura radiofônica. Eusébio confessa que o estilo "leve e sutil" de Raimundo Menezes tem "um sabor mágico, sugestionador, um fortíssimo poder de evocação" para trazer ao presente o "colorido" de outrora, em capítulos que vão da Fortaleza dos lampiões aos primitivos enterros; dos bondes de burros ao telefone número 1: "são resenhas bem curiosas de usos e costumes de outras eras que se foram e não voltam mais e que merecem ser lembrados para conhecimento dos coetâneos e dos porvindouros"10. Ouvir no rádio e ler no papel tornar-se-iam alívio e alento diante do tempo corrosivo: "Admiro e cultuo o passado e me sinto muito bem quando me deparo com alguma coisa que se relaciona com papéis velhos, pois a poeira que eles envolvem é mais suave e mais macia do que a poeira de todos os dias" ${ }^{\prime 1}$. 
termo "coisas que o tempo levou" havia se transformado em uma espécie de bordão, mote recorrente quando o assunto era memória. Ressaltava-se, desse modo, não a continuidade, mas a ruptura, a experiência urbana de Fortaleza como fenda no tempo, progresso que criava e destruía. Emergia, na cultura letrada, algo novo: a experiência da perda, a lamentação em torno da Fortaleza do século XIX, que deixava de existir para dar espaço a novas construções. $\bigcirc$ Museu Histórico do Ceará, visto de modo recorrente como símbolo da civilização, era contra e, ao mesmo tempo, a favor do progresso.

Em sua preferência pela poeira dos arquivos em comparação à "poeira de todos os dias", o diretor do museu encarnava, a seu modo, essa ambivalência intrínseca do progresso que, em nome do novo, destruía o velho e, mais ou menos na mesma proporção, costurava relações de saudosismo com as "coisas que o tempo levou".

No ano de criação do museu, 1932, também foi criado um novo código de posturas para Fortaleza, regulando uma quantidade mais ampla de itens para o ordenamento urbano, inclusive com um tópico sobre a poeira nas ruas, proibindo a limpeza de tapetes nas calçadas ${ }^{12}$. Tentava-se evitar o aumento do tipo de pó que não agradava ao diretor do museu e que, certamente, incomodava os outros habitantes. Resta saber sobre o sentido e a intensidade desse incômodo.

Em princípio, pode-se afirmar que, ao referir-se ao gosto pelo pó dos papéis guardados, Eusébio estava na contramão da ciência médica. Seu gosto realizava-se em nome de uma sensibilidade em decadência, quer dizer, a percepção dos antiquários, que valorizavam exatamente a presença de pedaços do pretérito envolvidos com o pó acumulado pelos anos.

Ora, a identificação entre poeira e doença não é algo fora do tempo. Foi na segunda metade do século XIX que a poeira começou a aparecer como perigo para a saúde, a partir de novas conclusões dos médicos sobre a propagação de doenças. $\bigcirc$ código de 1932, há pouco citado, está mais ou menos em acordo com a nova repulsa. Não se quer dizer, com isso, que antes a poeira era algo agradável, mas apenas que não tinha o aspecto perigoso que vem a ter com o desenvolvimento de teorias em torno do modo pelo qual os males podem ser transmitidos.

Como bem ressalta Alain Corbin a respeito do início do século XIX, "a poeira não entra no rol das preocupações" ${ }^{13}$. Conclusão que é minuciosamente observada por Luís de Camargo em sua tese sobre as doenças e a morte na São Paulo do século XIX. Isso não significa que a poeira passava despercebida. Dentro de casa ou na rua, o trânsito e o acúmulo do pó irritavam e eram desagradáveis, mas se tratava de algo inofensivo à saúde e, portanto, deveria ser suportado ${ }^{14}$.

A partir de 1905, o desenvolvimento de aspiradores de pó elétricos portáteis, como destaca Adrian Forty, pode ser relacionado com o medo das doenças escondidas na poeira. A sensibilidade negativa diante do pó ganhou largo espaço na publicidade e, além dos argumentos médicos sobre a
12. Cf. Prefeitura de Fortaleza (1933, p. 100).

13. Cf.Alain Corbin (1987, p. 170).

14. "Foi somente a partir de um período bem marcado na história que a poeira passa a ter um caráter pavoroso, representada como portadora e transportadora de um sem número de doenças através de sua suspensão e vôo no ar. Iniciava-se, nas duas últimas décadas do século XIX, uma neurose da poeira." Cf. Luís Soares de Camargo (2007, p. 214); grifos meus. 
15. Adrian Forty (2007, p. 242).

16. Cf.Antônio Luís M.e Silva Filho (2002,p. 98)

17. Ibidem.

18. Cf.Adrian Forty, (2007, p. 238).

19. Cf.Asmuce, (2007, p. 51). periculosidade da sujeira, é preciso considerar que passa a compor-se uma inextricável amarração entre higiene e beleza.

A idéia de que a limpeza poderia ser linda enraizou-se com tanta força que cada novo produto que ostentasse uma aparência de higiene era percebido pelos consumidores como uma genuína necessidade: longe de ser difícil de se adaptar, a limpeza era uma estética que satisfazia muitos desejos. No conjunto, o comércio alcançou mais sucesso do que os próprios higienistas jamais tiveram na promoção de padrões mais elevados de limpeza. [...] Aspiradores de pó, sabões em pó e máquinas de lavar criaram novas oportunidades para padrões mais elevados de higiene e fizeram do descaso com a limpeza algo mais visível e indesculpável, especialmente porque as novas regras do design faziam cada partícula de sujeira se destacar $^{15}$.

Antônio Luiz Macêdo, ao estudar os primórdios da oferta e do consumo de eletrodomésticos em Fortaleza, destaca um anúncio de 1941: "Um dos preciosos utensílios domésticos é a vassoura elétrica. Adaptável em qualquer tomada de corrente existente nas instalações elétricas domiciliares"16. A seguir, a propaganda argumenta sobre a principal vantagem do novo instrumento: "limpa de modo admirável o soalho, sem empoeirar os móveis"17.

Além de ser significativo o fascínio pela eletricidade, o anúncio ressalta o rigor que começava a ser necessário na limpeza. Com espanadores e vassouras comuns, a higiene tornava-se insatisfatória, na medida em que, ao juntar a poeira, também a espalhava. O novo invento, ao realizar somente o ato de "absorver a poeira"18, conforme a publicidade que se disseminava pelos centros urbanos, resolvia o dilema.

É no movimento dessas novas maneiras de perceber o mundo que o diretor do Museu Histórico do Ceará enfatiza sua preferência pelo pó dos papéis. Sua observação se encontra numa espécie de transição, ou melhor, numa ambiguidade insolúvel: intolerante com a rua do presente, e reverente diante dos arquivos. No seu entender, a beleza do acervo exposto não estava vinculada diretamente ao asseio que começava a ser exigido. Algum tempo depois, o museu iria embarcar na era dos aspiradores, quando os habitantes de Fortaleza já estavam habituados a ver anúncios de "vassouras elétricas" nos jornais e nas lojas.

\section{O pó e o desalinho}

Para ressaltar o tom de casa arrumada que havia no museu, o jornal A Rua publicou, em março de 1933, o seguinte comentário: "Admirando e analisando objetos e novidades, íamos constatando a magnífica organização e excelente disposição de tudo quanto se acha exposto e guardado"19.

Mas o que seria essa "magnífica organização"? E a "excelente disposição de tudo" também não fica muito clara. É certo que não havia um recorte temático ou cronológico, mas havia o quê? A certa altura, o repórter 
mostra um entendimento que não se encontra em nenhuma outra fonte, seja jornalística ou da lavra do diretor. Explica o motivo da divisão entre as duas salas: "A de objetos leves, como móveis, fotografias, medalhas, estandartes, bandeiras, cédulas etc., instalada na sala Antônio Bezerra; a de objetos pesados, como canhões, balas e semelhantes"... ${ }^{20}$

Divisão por peso. Mais parece ser a vontade de ordenamento do observador do que, propriamente, a proposta do diretor. De qualquer modo, a matéria está em sintonia com muitas outras observações publicadas no decorrer de sua gestão (1932-1942), no sentido de elogiar a boa organização do espaço. Mas não foi nesse tom reverente que a proposta museológica de Eusébio seria tratada por um dos sucessores na condução do museu. Nomeado diretor em dezembro de 1944, Hugo Catunda logo anunciou pela imprensa que seu rumo seria diferente:

O Museu não deve ser apenas um mostruário de objetos antigos, destinado à simples curiosidade, muitas vezes inconsciente, do público visitante. A sua organização deve prever, sobretudo, finalidades de ordem educativa pela valiosa contribuição objetiva que oferece aos estudiosos, aos que procuram interpretar, através das suas coleções, a inspiração artística, as tendências espirituais, o sentido cultural de cada época, na sua evolução constante e renovada [...] A disposição das coleções do Museu deve, pois, obedecer, por ordem e por época, esse sentido de diferenciação das tendências das gerações, para melhor facilitar o exame das suas modificações, através das idades. É o que procuraremos fazer ${ }^{21}$.

Percebe-se, então, que estão em jogo novas forças para a administração do passado. Não mais o acúmulo de peças. As coleções devem mostrar, em ordem cronológica, as "tendências das gerações". Não há clareza na proposta, nem como realizá-la concretamente no espaço expositivo, nota-se, porém, uma mudança de foco. Seria, então, o rompimento com a sensibilidade antiquária? Pode ser dada uma resposta positiva, mas uma negativa também faz sentido, pois as reformas pretendidas apresentam continuidades, na medida em que, apesar do impulso inovador, permanecem os fetiches em torno do "objeto curioso". $\bigcirc$ museu deveria mostrar "os motivos estéticos, as curiosidades de qualquer natureza que exprimam o gosto, as aptidões e as preferências das gerações" 22 .

Também em 1944, no jornal $\bigcirc$ Nordeste, um visitante publica seu parecer em uma crônica de título bastante significativo - Vendo e ouvindo coisas que o tempo levou:

Dou mais alguns passos e vejo um velho sino de bronze. Leio nas inscrições o nome de minha terra - Cascavel. Não quis mais saber de nada. E, infringindo a lei e os avisos - "É proibido tocar" - virei o bronze e espanei-o. Estava coberto de poeira. Era o velho sino pertencente à primeira igreja erguida em Cascavel. Suas inscrições rezam: "Nossa Senhora d'Ó - Cascavel - 1739 - pertencente àquela igreja, cuja construção começou em 1710"23.

Seria essa a primeira referência escrita sobre o aspecto negativo da poeira? Talvez, mas o que interessa aqui é destacar que ainda não se tem o 
24. Idem, p. 136.

25. Cf. Eusébio de Sousa (1943, p. 7) discurso sistematizado que, em anos posteriores, iria marcar presença. As críticas baseadas em torno da assepsia ainda estão vacilantes e vagas - mas não tardarão.

Quase quatro anos depois, mais precisamente no primeiro dia de março de 1948, Eduardo Campos publica uma matéria sobre sua visita ao museu. Denuncia que a "dotação de verbas" é vergonhosamente insuficiente para manter a instituição e argumenta: "Já não parece um Museu. É um depósito de velharias, de ferro velho, uma verdadeira despensa histórica de uma terra que se diz Terra da Luz"24.

Apesar das promessas de mudanças, aqui são vistas várias continuidades. Além da falta crônica de verbas para a manutenção básica, emerge uma forma de observar as peças que se faz presente desde a abertura das portas em 1933: o objeto isolado, formando, juntamente com muitos outros, uma miscelânea. Não só a divisão das salas não obedece a critérios cronológicos ou temáticos, mas trata-se, também, de uma concepção de história ainda muito vinculada ao colecionismo.

Estavam em pauta consonâncias e dissonâncias em torno do que seria a maneira correta de ajeitar o acervo exposto. Termos como antiquário e curiosidade, no caso das acusações de desarranjo, passam, a partir de determinada circunstância, a ser sinônimos depreciativos, revelando traços mais ou menos peculiares de um debate entre "antigos e modernos" que, embora tenha tido picos no século XIX, não desapareceu no século XX.

Mesmo com os ataques, o sentido do antiquário persistiu e ganhou resistência nos espaços de defesa da memória que se definem como "históricos". As práticas de Gustavo Barroso (no Museu Histórico Nacional) e de Eusébio de Sousa (no Museu Histórico do Ceará) podem ser tratadas na qualidade não simplesmente de sobrevivências, mas de pontos sobre os quais tensões e disputas em torno do passado ganham lugares concretos. Ambos misturaram colecionismo e patriotismo, os fragmentos e o todo, e, ainda, particularidades únicas sendo mescaladas ao sentido de progresso, e história científica com filosofia da história. Extrapolando as fronteiras nacionalistas de Gustavo Barroso, Eusébio de Sousa criou outras zonas de ambiguidade, que não apenas parecem beber em tratados oficiais, mas também nas tradições orais que valorizam "curiosidades" vindas de antanho, como se certos fragmentos do passado devessem entrar nos espetáculos de circo, junto com o homem que engole fogo ou a mulher que vive no meio das cobras.

Seu gosto por fardas e batalhas o fez publicar biografias de generais e uma coletânea de "casos curiosos" - o Anedotário da Guerra da Tríplice Aliança (1860-1870) -, com epígrafe de Gustavo Barroso: "As anedotas pintam o caráter dos homens melhor do que muitas páginas de psicologia"25. Apesar da circunscrição temática e cronológica, e ainda a promessa de análise psicológica, a sua escrita, quase sempre envolvida em julgamentos, cede espaço para o pitoresco, o fragmento que até pode ser exemplar, mas de tal modo se envolve com a particularidade dos fatos que passa a ser o veículo do acontecimento em 
si mesmo, refratário a qualquer costura da filosofia da história em sua pretensão de encadeamentos lógicos.

Assim, refaz-se o confronto com os antiquários, que hoje pode ser entendido em outra dimensão, quer dizer, na própria "memória da disciplina", que foi constituindo um campo de tensões nem sempre explicitado pelos descendentes (vitoriosos) de certos combates em torno dos modos pelos quais o passado chega ao presente, e como são desenvolvidos procedimentos para tratar as passagens do tempo. Os estereótipos diante dos antiquários, que os colocam na qualidade de conhecimento desarranjado e desconexo, movimentam-se no meio de uma "derrota da erudição" e em nome da filosofia da história, que vai dar um sentido de utilidade prática ao saber sobre o pretérito. Como bem ressalta Manoel Luiz Salgado, "estavam sendo postos em marcha dispositivos intelectuais que transformarão progressivamente este conjunto material em 'fontes' para a escrita da História"26.

Se há um confronto no plano da escrita da história, percebe-se, em medida semelhante, que o debate não se restringe a ele - um campo que, sobretudo no século XIX, vai se tornando cada vez mais específico, como também ressalta a análise de Manoel Luiz, referindo-se de modo especial ao romance de Walter Scott, inspiração máxima do que seria chamado "romance histórico". Em O Antiquário, publicado em 1916, Scott reproduz a imagem do colecionista como "amante das coisas do passado", como erudito que trabalha com objetos misturados e desprovido de método vinculado ao tempo presente ${ }^{27}$.

É claro, como já foi ressaltado, que Eusébio e seus "opositores" não estão reproduzindo a querela entre antigos e modernos, entre antiquário e história científica, mas há, em sua oposição, traços de semelhança, há certas repetições nas diferenças. Eusébio, quando assume a direção do museu, em 1932, deixa de ser juiz de direito apenas no plano oficial. Na verdade, não há propriamente uma troca de profissão, mas a utilização do universo do julgamento na própria escrita da história, como se a escrita em si fosse um tribunal - e a única instância válida para avaliar o passado que há nos artefatos. Isso, obviamente, o afastaria de modo radical da sensibilidade antiquária; mas procurar tal coerência significa apenas cair nas armadilhas de uma história do pensamento que não enxerga as ambiguidades, os cruzamentos que geram as especificidades das disputas em torno do que seria a "História do Ceará" e da responsabilidade do museu diante dessa história.

Um dos indícios dessa querela entre "antigos e modernos" (uso esses termos na falta de outros) é o texto que Raimundo Girão publicou no início de 1953, para marcar a sua direção para o novo ordenamento do museu, sob a tutela do Instituto do Ceará. Seu olhar enxergou "uma confusão à primeira vista irremovível", porque "a originária disposição do Museu, devida ao dr. Eusébio de Sousa, sofrera, com os tempos, dolorosa subversão". Até aqui, pode-se imaginar que Raimundo Girão retornaria ao museu original, para reparar a "dolorosa subversão" e, assim, recompor a proposta do primeiro diretor. Mas, no final das contas, a nova direção queria, apesar do respeito ao venerável Eusébio,
26. Cf. Manoel Luiz Salgado Guimarães (2008, p. 48).

27. Idem, p. 43. 
28. Cf.Asmuce (2007, p. 145).

29. Ibidem.

30. Ibidem.

31. Ibidem.

32. Ver Raimundo Girão (1960).

33. Ibidem.

34. Ibidem. um novo layout, não só para a exposição, mas para o modo de receber e incentivar doações. Os trabalhos de restauração e higienização foram acompanhados pela seleção do que ficaria no acervo, pois estava "tudo misturado, posto ali dir-se-ia a granel, sem nenhum critério de escolha, à medida que chegava"28. A ordem, que de início parece ser de recuperação do projeto inicial, passa a ser, sobretudo, a de arrumar a casa: "Era um museu de velharias, sem um sentido lógico. Parecia uma casa de ferro-velho. Uma barra funda. Aconteceu, no entanto, que a boa vontade e a coragem venceram os obstáculos e [...] foi-the dado outro caráter" 29 . Na sua definição, o plano foi criar "um museu regional, que documentasse ou retratasse as peculiaridades da região do Nordeste, especialmente do Ceará, no tocante à história e à antropologia"30.

E por que investir? A resposta, mesmo sintética, e com pretensões de novidade, reproduz ambiguidades de um período que se anunciava superado: "Os museus são grandes e majestosas vitrines que deliciam e instruem, que ativam a nossa sensibilidade artística e nos dão indizível prazer de reviver o passado" 31 . Permanecia, mesmo com a vontade de um "sentido lógico", o gosto pela miscelânea e o tom da relíquia que traz a sensação de "túnel do tempo", no qual cada objeto tem uma verticalidade única, sem muitas possibilidades de recortes temáticos, apesar das tentativas nesse sentido.

O "sentido lógico" reclamado por Raimundo Girão aparece, de modo mais sistematizado, no Guia do Visitante, publicado em 1960, com a seguinte divisão do espaço expositivo: Sala da Cidade, Sala do Sertão, Sala do Indio, Sala Eusébio de Sousa, e Sala dos Generais. Mas, os recortes temáticos não tinham uma fronteira muito clara. Sobre a Sala do Sertão, por exemplo, observase o seguinte:

Num dos mostruários da Sala encontra-se a roupa de vaqueiro, com seu gibão, seu guarda-peito, as perneiras, o chapéu e quantos outros complementos, inclusive a sela ou ginete e os seus arreios. Noutro, acham-se objetos de uso pessoal do Padre Cícero, o chamado "taumaturgo do Juazeiro", figura singular até agora ainda não definida com a precisa exatidão, apesar de tantos estudos a seu respeito. A mística das populações nordestinas, cada vez mais acentuada em torno do Padre Cícero, continua a desafiar as exegeses sociológicas. Conjuntos de arte popular e de cerâmica utilitária oferecem ao visitante motivos de incitante curiosidade ${ }^{32}$.

A Sala Eusébio de Souza era destinada à memória "dos grandes homens, desses que não deixaram no caminho da existência somente o rastro da passagem". Por outro lado, trazia objetos sem dono nomeado: "No centro, a jangada cearense, com toda a sua nomenclatura graciosa e estranha, qual símbolo de combatentes anônimos que enfrentam as fúrias do mar bravio [ $\ldots]^{\prime \prime 3}$. Além disso, o próprio catálogo avisa que nem tudo está muito definido: "Outros muitos objetos integram esta Sala, que recebeu o nome do fundador do Museu"34 
No início da década de 1970, houve um significativo aumento no número de visitantes, indo de 14.792 (em 1971) a 22.986 (em 1972), e isso não foi obra do acaso. O professor de história Osmírio Barreto, recém-empossado no cargo de diretor, estava fazendo uma intensa campanha para tornar o museu um lugar de visita escolar. Como mostra o relatório do Conselho Estadual de Cultura, seu empenho era muito bem visto. Na sessão do dia 28 de agosto de 1971, ele recebeu caloroso aplauso dos conselheiros ao defender que "o museu, antes de ser um relicário, é uma escola" ${ }^{\prime 3}$. Obviamente, na trajetória específica do museu, não era uma preocupação nova, mas soou como proposta patriótica de revitalização, diante das ondas de abandono que constantemente abalavam aquela "casa de memória".

A ação missionária de Osmírio, com boa repercussão na imprensa de Fortaleza, era uma iniciativa que expunha de modo mais aberto o sentido pedagógico característico de qualquer instituição museológica, na medida em que a exposição nunca é um ato inocente, sempre defende certo encadeamento de concepções que tomam lugar nas disputas da memória, fazendo ataques e defesas, nem sempre explícitas ou confessáveis.

No desejo de "dar aulas de história", Osmírio Barreto entendia a aula e a história em sintonia com a ditadura de 1964, que (como qualquer regime autoritário do século XX) defendia uma relação nacionalismo-passado, com a proposta de uma história exemplar, pronta para motivar o amor à pátria, reverenciando heróis que mostraram exemplos do passado para iluminar o presente e o futuro. Junto com a busca "da verdade", por meio de documentos confiáveis, vinha o romantismo do amor diante de bandeiras, medalhas e fardas, sem esquecer o valor de pequenos objetos, como a espátula de Clóvis Beviláqua ou um recipiente de vidro com a areia onde Pinto Madeira foi assassinado. Tudo isso em nome do Ceará e, sobretudo, do Brasil.

Ao mesmo tempo, essa engrenagem cujo sentido era o passado não conseguia se desvencilhar do gosto pelo pitoresco, da atração face a coisas exóticas ou curiosas, como se o historiador assumisse a condição de um banco de dados que, apesar do peso decisivo do ideal nacionalista, não conseguia livrar-se da fragmentação de verbetes. Pode-se perceber isso nos catálogo que o diretor publicou em 1972. Na listagem da Sala Eusébio de Souza há, por exemplo, os seguintes itens:

1. Galeria de ex-Presidentes e Governadores do Ceará;

2. Retratos dos ex-Presidentes da República, nascidos no Ceará:

A - Marechal Humberto de Alencar Castelo Branco:

B - Ministro José Linhares;

3. Fotografia histórica da Primeira Missa em Brasília

4. Retratos de cearenses ilustres:

A - Leonardo Mota;

B - Senador José Martiniano de Alencar;
35. Cf. Geraldo da Silva Nobre (1979, p. 103) 
36. Cf. Friedrich Nietzsche (2003, p. 29).

37. Ibidem.

38. Idem, p. 25.

39. Abdias Lima (1946, p. 141).
5. Vitrine com objetos de uso pessoal do Padre Cícero Romão Batista;

6. Vitrine com objetos de uso pessoal do Beato Lourenço;

7. Vitrine com capacetes, granadas e mão e outros objetos usados pelos nossos soldados na Revolução de 1930, e na de 1932, em São Paulo.

8. Vitrine com objetos usados pelos cearenses que participaram da gloriosa Força Expedicionária Brasileira na Itália.

9. Mesa em que foi assinada a sentença de morte de Pinto Madeira.

10. Objetos diversos.

É certo que havia uma intuição de criar recortes temáticos, como é o caso da Sala da Abolição, da Sala das Armas ou da Sala do Vaqueiro, mas mesmo assim predominava a relação fragmentada e romântica com o passado. Misturavam-se postulados de uma história exemplar, quase hagiográfica, com orientações e fundamentos advindos do século XIX, que colocavam o progresso da civilização moderna como o princípio constituinte das distinções entre passado, presente e futuro.

O cheiro do passado e o faro do historiador

Além do patriotismo, termo geralmente usado para enquadrar essa produção historiográfica da qual Eusébio de Sousa faz parte, há outros elementos que não deveriam ser ignorados, como é o caso da participação do próprio corpo na constituição dos contatos com o pretérito. $E$, nesse sentido, não é demasiado imaginar que a sensibilidade favorável à poeira pode oferecer pistas para discussões acerca do modo pelo qual o historiador, em determinadas circunstâncias, desenvolve sua escrita.

Em sua Segunda Consideração Intempestiva, Nietzsche identifica três modos de delinear o passado: o antiquário, o monumental, e o crítico. Sobre o modo antiquário, é ressaltado, entre outras coisas, esse apelo tátil, com destaque para o ar bolorento que tanto fascinava o diretor do Museu Histórico do Ceará. Para Nietzsche, essa "sede insaciável por novidade, ou, mais corretamente, por antiguidade" 36 é sentida quando o "homem envolve-se com um cheiro de mofo". A "mania antiquária", no final das contas, afeta todos os poros: "freqüentemente ele desce tão baixo que acaba por ficar satisfeito com qualquer migalha de alimento e devora com prazer mesmo a poeira de minúcias bibliográficas" ${ }^{\prime 37}$.

Possuidor dessa "alma preservadora e veneradora do homem antiquário"38, como diria Nietzsche, Eusébio de Sousa mobilizou-se para entrar em contato com o pretérito. Por outro lado, assumiu uma posição cientificista lque combatera os antiquários no decorrer do século XIX). No seu entender, o pesquisador conclui sobre o passado, e a conclusão equivale à verdade pesquisada. Toda sua determinação, ele a localiza na busca do "triunfo da verdade" 39 . 
Mas o sentido do passado não se restringia a isso. Havia uma emotividade que movimentava a escrita, talvez sob influência mais ou menos direta da sedução romântica exercida por Michelet nos leitores. $\bigcirc$ contato com o pretérito não se resumia ao raciocínio dedutivo ou indutivo, pois havia sentimentos em jogo, inclusive o sentir, de modo positivo ou negativo, a presença da poeira.

É claro que, na argumentação de Nietzsche, há uma desqualificação do antiquário, que foi sendo montada na própria querela envolvendo o modo correto de articular a fragmentação do passado. Por outro lado, é preciso perceber que, ao ser via de afeto, os eruditos - em suas maneiras de guardar e estudar os artefatos - acionariam o olfato em registros próprios. Não é à toa que Walter Scott recorre à capacidade de farejar para definir os verbos procurar e identificar:

Muchas fueran las cosas que le mostro; pero de lo que Oldbruck se hallaba verdaderamente orgulloso era de su biblioteca [...] Dotado de un verdadero olfato en materias bibliófilas, sabía descubrir com sagacidad los sítios en que alguno se deshacía de tales o cuales volúmenes, y atisbar entre éstos los que tenían valor positivo ${ }^{40}$.

Na análise feita por Stephen Bann, Walter Scott explica a Washington Irvin que existe, nas ruínas da abadia de Melrose, "uma rara seleção... como num queijo Stilton e com o mesmo gosto - quanto mais mofado, melhor" ${ }^{\prime 4}$. Em seus argumentos, Bann cita outro caso de "apetite pelo passado":

Du Sommerard, o fundador do Museus de Cluny, escreveu sobre seu "ardor pela ldade Média" [...] como estendendo-se a "objetos materiais", do mesmo modo que o de sir Walter Scott. Em outras palavras, este "ardor" estendia-se a objetos que podiam ser tocados e cheirados, se não efetivamente saboreados ${ }^{42}$.

Quando o tema é esquadrinhar o papel do cheiro na (falta de) qualidade de vida das pessoas e dos ambientes, Balzac - que tanto deu atenção aos odores - pode ser lido como conexão entre literatura e medicina ${ }^{43}$. Sua também impressionante capacidade de descrição dos objetos vai dar-nos indícios acerca de mudanças de sensibilidades, ou de zonas de ambiguidade, onde o pó acumulado sobre as coisas traria, além da repulsa, um tom contraditoriamente venerável:

A casa dos Cormon tinha também a sua biblioteca, que se achava situada um pouco abaixo do nível do Brillante, bem encadernada e resguardada. A poeira, ao invés de prejudicá-la, fazia-a valer. As obras eram ali conservadas com o cuidado que se dispensa, nessas províncias privadas de vinhedos, aos produtos cheios de natural, primorosos, recomendáveis por seus perfumes antigos e produzidos pelos prelos da Borgonha, da Turena, da Gasconha e do Sul. $\bigcirc$ preço dos transportes era muito alto para que se mandasse buscar vinho ordinário ${ }^{44}$.

Ora, tirando-se a acidez e alguns outros componentes balzaquianos, esse parece ser o lugar do pó no pensamento de Eusébio e de outros usuários do
40. Cf. Walter Scott (1955, p. 23).

41. Cf. Stephen Bann (1994, p. 146).

42. Idem, p. 147

43. "Atraído pela coincidência entre seres e lugares, Balzac faz um paralelo entre o cheiro específico dos cômodos e o temperamento dos indivíduos que neles habitam. Com isso, concorda com a intuição dos higienistas que associa a endemia da residência à originalidade da atmosfera familiar. [...] Balzac se compraz em restituir a ambiência olfativa de alguns locais semipúblicos: a farmácia, o salão de baile, o salão de concerto, o albergue, a sala de audiências. $O$ auge de sua repulsa é o cheiro de pensão." Cf. Alain Corbin $(1987$, p. 215$)$.

44. Cf. Honoré de Balzac (1990, p. 521). 
45. Cf. Mário Quintana (2006, p. 126).

46. Cf.Asmuce (2007, p. 145).

47. Cf. Mary Douglas (1991, p. 50 ). museu até a década de 1940. Essa poeira - que, ironicamente, ou não, agrega valor a uma biblioteca - já estava na listagem dos anátemas, mas Eusébio resistia. O prescritivo e preciso império que coloca na ordem do dia a limpeza de pele dos objetos não iria demorar.

Ainda no plano da ficção, mas dessa vez no âmbito do Brasil, é possível vislumbrar algumas sutilezas nessa (de)cadência da poeira. Em 1940, quer dizer, próximo do tempo em que Eusébio se definiu como amante dos arquivos, Mário Quintana começou a publicar, em jornal, os pequenos poemas que, 30 anos depois, seriam reunidos em Caderno H. No meio de uma infinidade de observações sobre a vida cotidiana, ele escreveu: "Ah, esses livros que nos vêm às mãos, na Biblioteca Pública e que nos enchem os dedos de poeira. Não reclames, não. A poeira das bibliotecas é a verdadeira poeira dos séculos" 45 .

O título do poema em forma de prosa - Veneração - não é desprezível. Assim, não é simplesmente a poeira, e sim a poeira carregada de outros sentidos, como o de ser o pó de uma biblioteca. Mas, também, o pó acumulado especificamente em um livro, conforme seu (des)uso ou a textura de seu papel. Pode ser, ainda, a poeira do tempo, anunciadora de um passado distante e misterioso. De qualquer modo, tudo indica que essa última opção revela o sentido no qual Eusébio está enredado. O pó que dá uma idade venerável aos papéis é o pó que the dá prazer. É por conta dessa reverência, também, que jornalistas daquela época não ressaltavam a limpeza como qualidade a ser exigida em uma exposição.

Sobre esse caráter escorregadio (ou essa ironia...) da poeira, tão bem percebida pelo poeta, os sucessores de Eusébio fizeram uma operação de transfiguração semântica, dando um sentido unívoco, com efeitos de sentido inequívoco portanto. Como já foi mencionado no tópico anterior, Raimundo Girão assumiu a direção do museu no intuito de renovar a instituição, que, ao seu olhar, estava completamente desarrumada: "Tudo em desordem, abandonado, entregue à poeira e ao cupim" 46 .

Há, portanto, uma percepção que se distancia do cheiro sentido por Eusébio de Sousa. À poeira é acrescentado um valor de desordem. Como bem ressalta a análise de Mary Douglas, "a impureza nunca é um fenômeno único, isolado"47. A matéria assim classificada pressupõe o ato de, em nome do limpo, repelir o sujo, ou melhor, o ato a favor de um novo ordenamento, do existente e de outras sensibilidades, para afastar o que é considerado como desordem. Sobre os objetos, não mais a "poeira dos séculos", mas a profilaxia do presente.

Depois de um certo hiato administrativo, Osmírio dá continuidade à gestão de Raimundo Girão. Gestão em sentido amplo, incluindo formas de gerenciar (ou agenciar) sensibilidades. Se, por um lado, podem perceber-se modificações nas maneiras de expor o acervo, por outro, há uma confirmação no tom higiênico. Os comentários registrados nos "livros de visitação" podem ser interpretados como indícios de uma sensibilidade que se distancia do "cheiro do passado": 
1971 - 26 de agosto. Ordem, asseio, amor à tradição histórica de nossa gente, é o lema do Museu, sob a provecta direção do prof. Osmírio de Oliveira Barreto. Somente assim poderá ser preservada a cultura, que não deve sofrer colapsos como em Alexandria, durante a dominação muçulmana.

1972 - 10 de fevereiro. Nesta data visitei o Museu Histórico do Ceará, que tem como diretor o professor Osmírio de Oliveira Barreto, cavalheiro imbuído de alto espírito público e perfeito organizador [...]. O Museu dá excelente impressão de asseio, distribuição de assuntos, organização adequada ${ }^{48}$.

Em 1985, Ciro Colares publica uma crônica sobre o museu, ressaltando a diversidade do acervo, e sem se preocupar com a divisão temática que o diretor imaginava realizada. Depois de descrever a variedade de objetos, ele conclui: "que se louve aqui a organização do Museu, tudo muito limpo, tudo muito bem arrumado, sem o mofo e sem o pó das coisas velhas" 49 .

Na exposição de 1997, não há mais o cheiro das "coisas que o tempo levou". A reportagem do dia 5 de abril de 1998, como outras publicadas na época, descreve o novo percurso expositivo:

Na mostra de longa duração encontram-se 10 alas com materiais históricos ou artísticos do acervo. A primeira tem as coisas do sertão, do mar e da serra, com o nome de "Terra da Luz, Sertão e Mar". O acervo seguinte está intitulado de "Que História é Essa?", um nome para designar os objetos que ainda são incógnitas, pois não se sabe de onde vêm e por isso dão margem à imaginação de cada um para criar sua própria versão da história. "Símbolos e Emblemas do Poder" é outra ala onde estão esses objetos e instrumentos de tortura. Para homenagear a Abolição dos Escravos, o acervo da "Escravidão e Abolição" tem ícones africanos, como a boneca do Maracatu. A cultura cearense pode ser conhecida melhor na ala "Letras e Artes", onde está também o painel com as principais figuras femininas. "Trincheiras e Barricadas" expõe a luta dos índios e faz um paralelo com movimentos como o dos Sem Terra e o Caldeirão. A religiosidade não poderia ser esquecida, e nesta parte tem Lampião citando Padre Cícero, cordéis, votos e outras manifestações populares. A descontração e o jeito pitoresco do povo cearense são ressaltados na ala intitulada "Ceará Moleque", como por exemplo o bode lôiô e um estofado de plástico prateado da Assembléia Legislativa Estadual. "Fortaleza Cidade Sol", "Indígenas Cearenses" e "Paleontológicas do Ceará" completam a mostra" ${ }^{50}$.

Fugindo da cronologia, a opção passa a ser o conhecimento da história com divisões temáticas, em uma cenografia rica em luzes, painéis e com a vontade de mostrar a síntese da história do Ceará a partir do acervo. Entra o "cenário interativo", em articulações de vitrines e luzes, para dizer que "coisa velha" é, na verdade, um "objeto da melhor idade". O faro muda e não é sem razão que uma jornalista afirma: "A intenção inicial do projeto é justamente quebrar a concepção tradicional e estática que a maioria das pessoas tem de que museu é sinônimo de mofo, cupins e velharias" ${ }^{51}$.

A realização de estudos comparativos sobre o impacto dessas "novas tecnologias" nos museus históricos seria significativa; e, no Brasil, os casos já
48.Ver Manoel S. de C.Jucá e José H. de Medeiros (1972, s. p.).

49. Cf. Ciro Colares (1985, p. 24-25).

50. Cf.Asmuce (2007, p. 268).

51. Idem, p. 262. 
Sem desprezar o nariz, era preciso reconhecer que, acima dele, estavam os olhos; e, ao lado, as orelhas. No dia 16 de janeiro de 1935, o discurso de Eusébio para recepcionar o famoso jurista cearense Clóvis Beviláqua é um indício sobre o funcionamento integrado entre o ver e o escutar:

Arquivo Público e Museu Histórico do Estado, onde as coisas e os homens do passado permanecem, residem e vivem, vivem mais do que nós, mais do que lá fora [...] tudo isso que aqui vemos nos mostruários, nas paredes e nos livros; tudo quanto aqui vive e a cada passo parece murmurar aos ouvidos do pensamento, ou mostrar-nos, aos olhos da alma, a recordação de um feito, o nome de um herói, a lição de um mestre, o exemplo de um patriota, o sacrifício de um mártir, a condenação de um réprobo, a absolvição de um inocente, a aclamação de um bravo e tantas outras impressionantes passagens, decisivas da historia de nossa terra! ${ }^{52}$

Na placa inaugurada, ficou gravado um texto cujo início é:

$$
\begin{gathered}
\grave{A} \\
\text { CLOVIS BEVILÁQUA } \\
\text { consagrado jurista } \\
\text { ESTADO DO CEARÁ } \\
\text { como recordação da visita } \\
\text { que se fez à terra natal. }
\end{gathered}
$$

Na falta de acervo, Eusébio criou um monumento cujo formato se aproximava mais de uma placa de rua do que de uma homenagem para ficar guardada do sol e da chuva. Para valorizar a inauguração, ele chega a dizer que, diante de muitos troféus, o valor da placa é bem mais significativo, porque celebra a luz da inteligência e da paz ${ }^{53}$.

Organizar para ver, ver para organizar. Articular o tempo no espaço do museu era, nesse sentido, expor objetos, arranjar materialidades memoráveis, para ficarem "nos mostruários" 54 . Na falta de relíquias, inventa-se uma placa, que também seria sacralizada. Bevilácqua, o cearense que havia estruturado o código civil, estava no auge de sua fama intelectual. Eusébio percebeu isso e fez, ao seu modo, o acervo aumentar. $\bigcirc$ importante era arrumar a casa, abrindo, da melhor 
forma, as visibilidades para o passado. Obviamente a maneira considerada melhor era circunscrita a determinadas expectativas sobre a possibilidade de transformar o passado em algo "visível" e, em certo sentido, também "audível". A inscrição seria uma maneira de quebrar o intrínseco silêncio dos objetos não marcados, em si mesmos, pela escrita. Seria uma espécie de objeto falante, mais do que os outros. Mas, no final das contas, todos os artefatos ali expostos teriam, conforme o diretor, a capacidade para "murmurar aos ouvidos do pensamento". Estava em cena o que se pode ouvir diante do "mutismo das coisas" 55, como diria Fancis Ponge.

Em outubro de 1944, o jornal $\bigcirc$ Povo publica uma notícia sobre o valor do acervo do museu, destacando a existência da "primeira máquina de costura que teria chegado ao Brasil". "Enquanto percorria, com o dr. Eusébio de Sousa, os compridos corredores do Museu", destacou o repórter, "somente os seus passos quebravam o silêncio" 56 .

Essa referência ao silêncio não seria uma observação isolada. No dia primeiro de junho de 1944, o jornal $\bigcirc$ Nordeste publica, sobre as "curiosidades" do museu, mais um relato, que assim inicia: "A máquina impressora do jornal parava. Deixo a redação. Os trabalhos do dia estavam terminados. Rumo para - Museu Histórico. Sei onde estão guardadas as 'coisas que o tempo levou'"57. prédio é visto como "majestoso" e a entrada é tratada como uma espécie de fronteira entre o passado e o presente: "Galguei os degraus de mármore, indo para onde estava um senhor de preto. Era o encarregado do livro de visitas. Assinei-o. Reinava um silêncio profundo" 58 .

Em julho de 1945, outro jornalista destacou que era preciso sentir o mutismo que há nos os objetos: "O silêncio, profundo silêncio, que envolve aquele casarão sombrio..." 59 . No princípio de tudo, estaria o vazio acústico de cada artefato. Em tom de reverência e mistério, o texto se refere às "antigas e enferrujadas peças de artilharia". Eram "símbolos da força e da juventude dos nossos antepassados", em contraste com a mudez da falta de uso: "Silenciosas, elas pareciam dedos levantados para o céu, exigindo, numa música impressionante, o silêncio e o respeito que se faziam necessários naquela casa veneranda" 60 .

Silêncio dos objetos, sem dúvida, mas também o silêncio do visitante respeitoso. Está em cena um ritual de reverência que, na ausência de sons, é feito como veículo de uma experiência sensorial com a materialidade exposta. É como se o audivel fosse uma mancha, uma quebra de comunicação entre o visitante e a coisa visitada. Circunscreve-se, assim, um corpo regrado em determinado sentido, diferente do corpo presente nas chamadas "sociedades arcaicas", como bem destaca José Gil:

Para nós, as palavras "gravidade" e "seriedade" reenviam para atitudes corporais que os primitivos ignoram. Elas não exprimem necessariamente o respeito por meio do silêncio, de gestos compassados - como nós, no culto religioso; as suas cerimônias acompanham-se de risos e de todas as espécies de manifestações que nós facilmente qualificaríamos de sacrílegas ou de pagã $s^{61}$.
55. Ao referir-se às motivações de sua poesia, Francis Ponge confessa: "O que me sustenta ou me empurra, me obriga a escrever, é a emoção provocada pelo mutismo das coisas que nos cercam.Talvez se trate de uma espécie de piedade, de solicitude, enfim, tenho o sentimento de instâncias mudas da parte das coisas, solicitando que finalmente nos ocupemos delas, que as digamos"; Cf. Francis Ponge (1997, p. 85).

56. Cf.Asmuce (2007, p. 109).

57. Idem, p. 115

58. Ibidem.

59. Idem, p. 121.

60. Ibidem.

61. Cf. José Gil (1997, p. 67) 
62. Cf. Bruno Jacomy (2004, p. 161).

63. Ibidem.

64. Cf.Asmuce (2007, p. 281).

65. Idem, p. 268
Por outro lado, surgiram propostas museológicas que passaram a compreender que o silêncio deveria ser rompido. As renovações pelas quais os museus passaram na segunda metade do séc. XX incluíram, de variadas maneiras, especial atenção ao "patrimônio sonoro". O som passa a ser componente da defesa da memória, como se percebe na ânsia com que Bruno Jacomy prega a necessidade de elementos audíveis nas exposições:

Não é porque se reproduz um ambiente muito realista que o visitante se sentirá necessariamente tocado, emocionado. É indispensável que haja uma harmonia entre o visto e o ouvido. Por exemplo, talvez seja mais coerente difundir, perto dos teares, trechos de canções populares nas quais a voz imita o ruído do tear do que reproduzir os sons reais, cuja ligação direta com as operações que se produzem na máquina - que, além disso, está imóvel - o visitante não compreenderáb2.

Aparentemente fundamentados na renovação dos museus por meio de uma história social da vida cotidiana, seus argumentos se encerram de maneira triunfante e nostálgica: "A audição, como o paladar ou o olfato, perdeu a função vital da nossa animalidade primitiva. [...] Não nos privemos, hoje, dos prazeres que esses sentidos podem nos oferecer"63.

O som teria, para Jacomy, a função de aumentar a suposta realidade do objeto, reproduzindo (ou recriando, de alguma forma) o som que ele antes fazia. $\bigcirc$ que passa a ser valorizado, portanto, não é propriamente o som como documento histórico a ser interpretado, e, sim, a inserção de mais um componente no cenário, mais um "recurso expositivo" para dar a impressão de "passeio pelo passado". No final do século XX, tal movimento de reprodução de cenários e de outras tentativas de aproximar o visitante da coisa visitada ganhou vitalidade impressionante. Foi nessa onda que, em 1997, o Museu do Ceará publicou o fôlder Túnel do Tempo, com o intuito de atrair público para a nova exposição:

Museu do Ceará oferece uma oportunidade única de se conhecer o Ceará da natureza e a natureza do cearense. Através das peças de sua exposição permanente, você vai merguIhar nas lutas, crenças e cultura de um povo que soube provar, ao longo da sua História, que a vontade de vencer nasce dentro da alma e que, apesar dos pesares importante é manter o humor 64 .

Aí está a proximidade pregada pelos que "amam o passado", mas não com "objetos velhos" ou "relíquias". Pela imprensa, a curadora da nova "exposição permanente" afirma que o futuro e o presente passam a ter mais peso, pois "ninguém quer saber do passado" 65 .

Há uma ambiguidade aí: negação e afirmação do passado. O velho desperta interesse, mas exposto por meio de novidades. $\bigcirc$ antigo ganha força se estiver em um "museu do futuro", quer dizer, em uma cenografia atraente, na medida em que usa de recursos inovadores, geralmente elétricos (e de preferência eletrônicos), que causem efeitos de surpresa e admiração. Ao inserir um "fundo musical", a curadora pretendev exatamente isso: despertar o encantamento diante 
de "coisas que o tempo levou". Em ambiente escuro, com expositores de cor preta e luzes estrategicamente direcionadas, o visitante entraria no túnel mnemônico, pretensamente preparado para a distribuição de passagens.

Nessa sonorização, com músicas de autores cearenses, a intenção foi fazer com que os visitantes fossem envolvidos na "atmosfera" da exposição. Por outro lado, é possível imaginar que o próprio silêncio tivesse entrado em decadência diante da vontade de comunicar com mais intensidade, tal como se percebe na avalanche de informações visuais e sonoras que caracteriza o comércio nos centros urbanos ${ }^{66}$. Além disso, há uma tradição da racionalidade ocidental que coloca o silêncio como coisa negativa, chegando a ser até indício de algo terrível, que causa insegurança e medo ${ }^{67}$.

No final das contas, nada de muito seguro se pode dizer sobre o vácuo sonoro ou o acúmulo da poeira. Ora positivo, ora negativo. Se, em um momento, valoriza-se o tom religioso do pó e do silêncio, que dá ao museu um caráter venerável, em outras ocasiões, não necessariamente em outros períodos cronológicos, há outros sentidos. $O$ silêncio pode tornar-se uma falha, a ser preenchida pelo som de um "fundo musical", em interação com o acervo exposto. $\bigcirc$ pó fica proscrito, ora por receitas de estética, ora por orientações médicas. Para uns, o silêncio favorecia a visão diante das peças. Para outros, a música é que seria melhor para ver mais. Nisso tudo, o que fica claro é que o museu acabou por constituir um espaço que, ao exibir objetos, não convocava somente os olhos, mas também os ouvidos, a pele e o nariz.

A aprovação de um novo código de posturas para Fortaleza em 1932, ano em que também se cria o museu, pode indicar traços dessas (mudanças de) sensibilidades. Como já foi ressaltado, há um artigo que, entre outras proibições "na via pública", trata do pó dos tapetes:

Estender roupas ou outros objetos a enxugar ou arejar, limpar vazilhas; joeirar gêneros; assoalhar peixe; matar ou pelar animais; ferrar, sangrar ou fazer algum curativo a qualquer animal, excerto em caso de urgência; partir lenha; cozinhar; torrar café; estender couros; sacudir tapetes; esteiras; ou coisas semelhantes; urinar ou defecar fora dos sumidouros públicos ${ }^{68}$.

Se tais restrições são entendidas na perspectiva do saber médico, é lógico concluir que, nas divisões do código, elas fazem parte das medidas sanitárias. Mas, nesse sentido, é interessante notar que não estão no título VI, "Da polícia Sanitária", e sim no IV, "Da polícia de trânsito, dos costumes e da tranquilidade pública", mais especificamente no capítulo III "Dos Costumes e aspecto geral da cidade". Não havia, ainda, uma clareza sobre o perigo sanitário do pó. $\bigcirc$ incômodo vinculava-se ao trânsito e à tranquilidade.

É claro que o código, em sua complexidade normativa, compõe-se de partes interligadas, mas a maneira de dividir os temas sugere formas de sentir os problemas e as soluções. Além disso, a existência da norma, como se sabe, pressupõe a própria concretude da coisa a ser normatizada, dando margem para se supor sobre a presença de conflito em comportamentos e valores. Assim, é plausível imaginar que a poeira do museu administrado por Eusébio de Sousa
66. "O nosso imaginário social destinou um lugar subalterno para o silêncio. Há uma ideologia da comunicação, do apagamento do silêncio, muito pronunciada nas sociedades contemporâneas. Isto se expressa pela urgência do dizer e pela multidão de linguagens a que estamos submetidos no cotidiano.Ao mesmo tempo, espera-se que se esteja produzindo signos visíveis (audíveis) o tempo todo. Ilusão de controle pelo que 'aparece': temos de estar emitindo sinais sonoros (dizíveis, visíveis) o tempo todo." Cf. Eny P. Orlandi (1992, p. 37).

67."A contemplação do silêncio absoluto tem-se tornado negativa e aterradora para $o$ homem ocidental. Assim, quando o infinito do espaço foi sugerido pela primeira vez pelo telescópio de Galileu, o filósofo Pascal ficou profundamente temeroso ante a perspectiva do silêncio eterno." Cf. R. Murray Shafer (2001, p. 355).

68. Ver Prefeitura de Fortaleza (1933, p. 100). 
69. Ibidem.

70. Ver Maurice Merleau-Ponty (1999). passou, por indicações sanitárias, a incomodar; mas o incômodo também provinha da própria noção de ordenamento que o mundo urbano começava a exigir.

A respeito dos sons, vale a pena transcrever as proibições do capítulo II do título IV, referente à "polícia de trânsito, dos costumes e da tranquilidade pública":

1 - Dar gritos à noite dentro das zonas central e urbana, depois das 22 horas, sem necessidade ou utilidade;

2 - discutir ou altercar em altas vozes nas ruas, praças, passeios ou casas de entrada públi$\mathrm{ca}$;

3 - dar tiros a qualquer hora do dia ou da noite, não sendo no desempenho de deveres do serviço público ou nos casos de legítima defesa da pessoa ou da propriedade;

4 - tocar ou ensinar música, com pancadaria, depois das 22 horas, sem licença da Prefeitura, exceto nos locais permitidos;

5 - usar sinais sonoros, tímpanos, buzinas e outros meios de aviso, fora dos casos estritamente necessários;

6 - usar o escapamento livre dos veículos nas zonas central, urbana, e suburbana.

Art. 400 - Nas imediações dos hospitais, sanatórios, casas de saúde, e manicômios, etc., não será admitida, durante a noite, realização de espetáculos ruidosos, batuques nem o uso de foguetes, tiros ou quaisquer festejos incomodatícios ${ }^{69}$.

Se nos acúmulos que caracterizam o urbano (a partir do século XIX) tudo deve ser acumulado dentro de regras da convivência, não é de se admirar que o som tenha destaque. Seria uma saída fácil afirmar que as cidades se fundam na multiplicidade de sentidos - contra e a favor dos elementos sonoros. Seria uma conclusão geral, ou melhor, uma redução geral, pois é preciso levar em consideração as tensões, as disputas socialmente constituídas, que, no termo diversidade, inserem o sentido de divergência. Aqui, isso significa tratar tais sensibilidades no interior dos conflitos em torno do que é aceitável e do recomendável - que também as constituem (e que estão no jogo de definição do espaço museológico) -, ou seja, daquilo que facilita ou atrapalha os contatos com o passado. Ao ser ponto fundante da vida em sociedade, o pretérito convoca recursos variados, que vão dos olhos aos ouvidos, do nariz ao resto do corpo. Está em questão a vulnerabilidade dos poros, ou melhor, o limite cambiante entre a pele e a paisagem, entre a carne do corpo e a carne do mundo, como diria Merleau-Ponty ${ }^{70}$.

Os sentidos do passado e a presença dos sentidos

A poeira e o silêncio, em suas muitas figurações, faziam parte da maneira pela qual o museu era percebido. Nas maneiras de fazer ligações entre 
o presente e o passado exposto, a visão tinha certa preponderância, mas não estava isolada. É por isso que os visitantes (e os diretores) do Museu do Ceará deixaram suas impressões não somente sobre o que foi visto ou sobre o que desejavam ver, mas também sobre o silêncio e a poeira.

Longe de estabelecer a mentalidade típica de um determinado período, o que se busca aqui é uma abordagem sobre a historicidade da percepção diante do espaço museológico. Trata-se de um esforço interpretativo, no sentido de enfocar os modos pelos quais o passado é apreendido pelas circunstâncias do presente. Apreensão que, além de ser plural, mobiliza trânsitos e interdições que assumem valor de princípios de normalidade e necessidade.

Quando se estuda a historicidade dos museus levando-se em consideração o caráter circunstancial e mutante do objeto exposto, é preciso pensar a respeito das sensibilidades que constituem as maneiras de ser de cada objeto no tempo e no espaço. Isso significa tornar-se necessário traçar a biografia dos objetos ${ }^{71}$.

Ao assumir a condição de "exposto", o objeto entra em metamorfoses que dependem dos modos pelos quais as memórias são historicamente constituídas. Afinal, o museu não se define simplesmente como lugar de guardar e expor artefatos. No espaço museológico, o que acontece, antes de tudo, é a metamorfose de objetos, em simbiose com o poder da memória e a memória do poder, em suas mais variadas manifestações. Memória que depende de forças socialmente engendradas e, portanto, não deve ser interpretada como simples resultado de operações racionais de uma lógica universal e abstrata.

$\bigcirc$ passado, portanto, não é simplesmente aquilo que passou. A depender do modo pelo qual o presente requisita traços de permanências ou de rupturas, o que foi transcorrido vai assumindo determinados papéis. Em operações variadas, o pretérito vai ganhando sentido não como presença transmitida através do tempo, e sim como o saber que se constrói nas disputas de posições conflitantes e interessadas em criar certas legitimidades no presente - e a partir do presente.

\section{REFERÊNCIAS}

ASMUCE [Associação Amigos do Museu do Ceará]. Museu do Ceará 75 Anos. Fortaleza:Asmuce, 2007.

BALZAC, Honoré de.A solteirona. In: BALZAC, Honoré de. A comédia bumana, 6. São Paulo, Globo, 1990. p. 483-597.

BANN, Stephen. As invenções da bistória: ensaios sobre a representação do passado. São Paulo: Editora da Unesp, 1994.

BARROSO, Henrique Medeiros. Museu Histórico e Antropológico. 50 anos (1933-1983). Fortaleza: Secretaria Estadual de Cultura e Desporto, 1983.

BOSI, Ecléa. O tempo vivo da memória: ensaios de psicologia social. São Paulo: Ateliê Editorial, 2003.
71. Como ressalta Ulpiano Bezerra de Meneses, os artefatos têm trajetórias específicas:"para traçar e explicar as biografias dos objetos é necessário examiná-los 'em situação', nas diversas modalidades e efeitos das apropriações de que foram parte". Para tal empreendimento, não caberia a recomposição de um suposto ambiente de origem: "Não se trata de recompor um cenário material, mas de entender os artefatos na interação social"; cf. Ulpiano Bezerra de Meneses (1998, p. 92.). 
CAMARGO, Luís Soares de. Viver e morrer em São Paulo: a vida, as doenças e a morte na cidade do século XIX. 2007. Tese (Doutorado em História Social) - Pontifícia Universidade Católica de São Paulo, São Paulo, 2007. Disponível em: http://www.sapientia.pucsp.br//tde_busca/arquivo. php?codArquivo=5542.

CERTEAU, Michel de. A escrita da bistória. Rio de Janeiro: Forense Universitária, 1982.

A cultura no plural. São Paulo: Papirus, 1995.

COLARES, Ciro. Fortalezamada: roteiro para os amantes de uma cidade. Fortaleza: Nação Cariri; Livraria Gabriel, 1985.

CORBIN, Alain. Saberes e odores: o olfato e o imaginário social nos séculos dezoito e dezenove. São Paulo: Companhia das Letras, 1987.

DOUGLAS, Mary. Pureza e perigo. Ensaio sobre as noções de Poluição e Tabu. Lisboa: Edições 70, 1991. (Perspectivas do Homem, 39).

FORTY,Adrian. Objeto de desejo: design e sociedade desde 1750. São Paulo: Cosac Naify, 2007.

GIL, José. Metamorfoses do corpo. Lisboa: Relógio D’Água, 1997.

GIRÃO, Raimundo. Guia do visitante do Museu Histórico e Antropológico do Ceará. Fortaleza: Imprensa Universitária do Ceará, 1960.

Pequena História do Ceará.4. ed. Fortaleza: Edições UFC, 1984.

GUIMARÃES, Manoel Luiz Salgado. Reinventando a tradição: sobre antiquariado e escrita da história. In: RIOS, Kênia Sousa; FURTADO FILHO, João Ernani (Org.). Em tempo: história, memória, educação. Fortaleza: Imprensa Universitária - UFC, 2008.

HOLANDA, Cristina Rodrigues. Museu Histórico do Ceará: a memória dos objetos na construção da história (1932-1942). Fortaleza: Museu do Ceará; Secretaria da Cultura do Estado do Ceará, 2005.

JACOMY, Bruno. A era do controle remoto: crônicas da inovação técnica. Rio de Janeiro: Jorge Zahar, 2004.

JUCÁ, Manoel Sedrim de Castro; MEDEIROS, José Hortêncio de. Monografia do Museu Histórico e Antropológico. Homenagem do Museu Histórico e Antropológico do Ceará à pátria, nos festejos de seu sesquicentenário da Independência. Fortaleza: Secretaria Estadual de Cultura, Desporto e Promoção Social, 1972.

LIMA,Abdias. Falam os intelectuais do Ceará. Fortaleza: Imprensa Oficial, 1946.

MENESES, Ulpiano T. Bezerra de. Memória e Cultura Material: documentos pessoais no espaço público. Estudos Históricos. Rio de Janeiro, v. 11, n. 21, p. 89-104, 1998.

Comentário XII: visões, visualizações e usos do passado. Anais do Museu Paulista, São Paulo, v. 15, n. 2, p. 117-123, jul.-dez. 2007.

MENEZES, Raimundo de. Coisas que o tempo levou... (Crônicas históricas de Fortaleza antiga). Fortaleza: Livraria Edésio, 1938.

MERLEAU-PONTY, Maurice. Fenomenologia da percepção. São Paulo: Martins Fontes, 1999.

MOMIGLIANO,Arnaldo. As raízes clássicas da bistoriografia moderna. São Paulo: Edusc, 2004.

MUSEU DO CEARÁ.Tunel do tempo. Fôlder. Fortaleza: Museu do Ceará, 1991. 
NIETZSCHE, Friedrich. Segunda consideração intempestiva: da utilidade e desvantagem da história para a vida. Rio de Janeiro: Relume Dumará, 2003.

NOBRE, Geraldo da Silva. Para uma bistória cultural do Ceará: o Conselho Estadual de Cultura (1966-1976). Fortaleza: Henriqueta Galeno, 1979.

OLIVEIRA, Raimundo Eufrásio (Org.). Sinopse do Museu Histórico e Antropológico do Ceará. Fortaleza: Secretaria Estadual de Cultura e Desporto, 1987.

OLIVEIRA, Ana Amélia Rodrigues de.Juntar, separar, mostrar: memória e escrita da história no Museu do Ceará (1932-1976). Fortaleza: Museu do Ceará; Secult, 2009.

ORLANDI, Eni Puccinelli. As formas do silêncio: no movimento dos saberes. Campinas: Editora da Unicamp, 1992.

ORWELL, George. 1984. São Paulo: Nacional, 1991.

PONGE, Francis. Métodos. Rio de Janeiro: Editora, 1997.

PREFEITURA DE FORTALEZA. Código de Posturas do Município de Fortaleza. Fortaleza: [s.n.],1932.

QUINTANA, Mário. Caderno H. São Paulo: Globo, 2006.

RAMOS, Francisco Régis Lopes. A danação do objeto: o museu no ensino de história. Chapecó: Argos, 2004.

RAMOS, Iolanda Freitas. O poder do pó: o pensamento social e político de John Ruskin (18191900). Lisboa: Fundação Calouste Gulbenkian; Fundação para a Ciência e a Tecnologia, 2002.

REIS, Clóvis de Matos; OLIVEIRA, Raimundo Eufrásio (Org.). Monografia do Museu Histórico e Antropológico do Ceará. Fortaleza: Secretaria Estadual de Cultura, Desporto e Promoção Social, 1976.

SOUSA, Eusébio de. Tibúrcio: o grande soldado e pensador. Fortaleza: Urânia, 1937.

"Carta a Raimundo de Menezes". In: MENEZES, Raimundo de. Coisas que o tempo levou. Fortaleza: Edésio, 1938. p. 05-07.

SOUSA, Eusébio de. Anedotário da guerra da tríplice aliança (1865-1870). Rio de Janeiro: Gráfica Laemmert, 1943.

História Militar do Ceará. Fortaleza: Instituto do Ceará, 1950.

TAUNAY,Afonso de E. Um prefácio que não foi escrito para este livro. In: SOUSA, Eusébio de. Tibúrcio: o grande soldado e pensador. Fortaleza: Urânia, 1937. p. 03-07.

SCOTT, Walter. El anticuario. México: Cumbre, 1955.

SCHAFER, R. Murray. A afinação do mundo. São Paulo: Editora da Unesp, 2001.

SILVA FILHO, Antônio Luiz Macêdo e. Paisagens do consumo: Fortaleza no tempo da Segunda Grande Guerra. Fortaleza: Museu do Ceará, 2002.

Rumores: a paisagem sonora de Fortaleza. Fortaleza: Museu do Ceará, 2006.

Artigo apresentado em 9/2009. Aprovado em 3/201 1.

Annals of Museu Paulista. v. 19. n.1. Jan.-June 2011. 